\title{
Effect of Dietary Onion, Garlic, Red Pepper and Anise as Natural Feed Additives on Some Hematological Studies of Japanese Quail Chicks
}

\section{SA Abd El- Latif*, MA Toson and HA Mehany}

Animal and Poultry Production, Department Faculty of Agriculture, Minia University, Minia, Egypt

*Corresponding Author: SA Abd El- Latif, Animal and Poultry Production, Department Faculty of Agriculture, Minia University, Minia, Egypt.

Received: July 22, 2019; Published: August 28, 2019

DOI: $10.31080 /$ ASNH.2019.03.0428

\begin{abstract}
A total number of 300 quail chicks one week old were randomly divided into 5 treatments groups (60) chicks each group was subdivided into 3 replicates of 20 chicks each to study the effect of some natural feed additives such as onion powder, garlic powder, red pepper, and anise as natural feed additives on some productive responses of Japanese quail chicks. Birds fed 5 experimental dietary groups as follows:- the 1st group was fed on a basal diet without feed additives (control), the 2nd group was fed on a basal diet supplemented with $0.5 \%$ onion powder, the $3 \mathrm{rd}$ group was fed on a basal diet supplemented with $0.5 \%$ garlic powder, the 4 th group was fed on a basal diet supplemented with $0.5 \%$ hot pepper, and the 5 th group was fed on a basal diet supplemented with $0.5 \%$ anise. The experimental treatments started from 2 weeks old until 6 weeks of age. After 5 weeks from beginning of the experiment, 3 chicks from each treatment were injected intravenously in brachial vein with $0.2 \mathrm{ml}$ of $10 \%$ suspension of sheep red blood cells to determine the activity of antibody. Three birds within each treatment were randomly selected and sacrificed, after six weeks from beginning of the treatments. Blood samples were collected in tubes contained heparin as an antic agglutination substance to study blood physical characteristics. The data reviled that, the greatest numerically improvement $(\mathrm{P}>0.05)$ in packed cell volume and MCV was recorded for birds fed dietary onion. Birds dietary anise presented the pest $(\mathrm{P}>0.05)$ values of $\mathrm{MCH}$ compared with other dietary treatments. Birds fed dietary garlic and anise recorded the greatest $(\mathrm{P}<0.01)$ values of total immunoglobulin compared with all dietary groups. The greatest $(\mathrm{P}<0.01)$ values of total immunoglobulin were recorded for birds fed dietary garlic and anise compared with all dietary groups. No significant $(\mathrm{P}>0.05)$ difference was detected in the values of Heterophil \%, lymphocyte \%, Heterophil : lymphocyte (H: L) ratio \%, monocyte \%, Eosinophils \%, and basophil \% of Japanese quail birds fed all dietary treatments.
\end{abstract}

Keywords: Blood Characteristics; Natural Feed Additives; Quail Chicks

\section{Introduction}

In poultry nutrition, it is a solid fact that feeding cost is considered the most expensive item in the whole production process. Therefore, attempts are usually made to reduce feed cost without adversely affecting performance or product safety. Feed additive are classified into two categories: 1 st those essential for the biological function of birds as in vitamins and trace elements, whereas, the 2 nd category includes additives not essential for biological function, but have demonstrated a positive effect on bird's as in growth promoters, absorption enhancers, anti-microbial agents and metabolic modifiers [1-6]. As a result, supplementing broiler diets with some feed additives may be considered as an alternative to improve growth and feed conversion efficiency.

The use of antibiotic growth promotants (AGP) to improve animal performance has been practiced during last 50 years. However, when animals are exposed to low levels of antibiotics, resistant cells survive and grow producing antibiotic-resistant populations.
Consequently, the use of AGP in food animals has been banned in the European Union [7] and many other countries. In this con-text, alternatives to AGP are of importance. Most supplements which use as alternatives to AGP have effects on gut microflora, either directly or indirectly [8]. Using Herbs, spices, and various plant extracts have received increased attention as possible alternatives to AGP, since they are considered as natural products [9].

Medicinal and aromatic plants are cultivated in large areas in Egypt, about 48 thousands feddans were cultivated with medicinal and aromatic plants in Egypt [10]. Aromatic plants and essential oil extracted from them have been used as alternatives to antibiotics. For this reason, these plants are becoming more important due to their growth promoting and antimicrobial effect on animal health [11]. Medicinal plants has an effective compounds in their tissues including phenols and polyphenols, terpenoids and essential oils, alkaloids, lectins and polypeptides and other compounds applied antibacterial and immune stimulation effects [12] digestive pro- 
cess stimulation [13], reducing levels of blood fat and cholesterol [14], antioxidant property [15] and finally the growth stimulator [16]. Feed additives such as onion, garlic, red pepper and anise. Onion has the properties of strengthening the immune system. Previous studies suggest that the biological properties of onion are widely related to sulfur-containing compounds [17]. Moreover, garlic has several beneficial effects on both humans and animal having antimicrobial, antioxidant properties [18]; antiviral [19] and antifungal [20].

Therefore, the present study conducted to speculate the effects of adding some natural feed additives such as, dried onion(Allium cepa), dried garlic(Allium sativum), red pepper(Capsicum annum. L), and anise (Pimpinella anisum) at the levels of $0.5 \%$ each to growing Japanese quail diet to enhance some productive responses.

\section{Materials and Methods}

This study was carried out at the farm of Animal and Poultry Production, Faculty of Agriculture, Minia University, during the period from 28 May to 27 June 2016. It was designed to study the effect of some herbal feed additives such as, onion powder, garlic powder, red pepper and anise as natural feed additives on some productive and physiological response of Japanese quail chicks.

\section{Experimental birds}

A total number of 300 quail chicks one week old were randomly divided into 5 treatments groups (60) chicks each. Each group was subdivided into 3 replicates of 20 chicks each. The birds were housed in an open house in cleaned and fumigated battery cages (100x70x20). Feed and were offered to the birds during the experimental periods (2-6 weeks of age) ad-libtum. All chicks were reared under similar hygienic and environmental condition.

\section{Experimental diets}

Birds of the all experimental groups were fed on commercial basal diet (25\% CP and $2945 \mathrm{Kcal} \mathrm{ME} / \mathrm{Kg}$ diet) according to National Research Council, NRC, (1994) as follows:- The $1^{\text {st }}$ group was fed on a basal diet without feed additives (control), the 2nd group was fed on a basal diet supplemented with $0.5 \%$ onion powder, the $3^{\text {rd }}$ group was fed on a basal diet supplemented with $0.5 \%$ garlic powder, the $4^{\text {th }}$ group was fed on a basal diet supplemented with $0.5 \%$ hot pepper and the 5 th group was fed on a basal diet supplemented with $0.5 \%$ anise. The formulation and proximate analysis of the experimental basal diets (percent as fed) reported in table 1.

Premixes contributed the following nutrients per kilogram of complete feed: vitamin A, 2,300 IU; vitamin D3, $400 \mathrm{IU}$; vitamin E, $1.8 \mathrm{mg}$; vitamin B12, $3.5 \mathrm{mg}$; riboflavin, $1.4 \mathrm{mg}$; panthotenic acid, $2 \mathrm{mg}$; nicotinic acid, $7 \mathrm{mg}$; pyridoxine, $0.25 \mathrm{mg}$; folic acid, $0.15 \mathrm{mg}$; menadione, $0.3 \mathrm{mg}$; thiamin, $0.15 \mathrm{mg}$; manganese oxide, $35 \mathrm{mg}$; ferrous sulfate $35 \mathrm{mg}$; zinc oxide, $30 \mathrm{mg}$; copper sulfate, $60 \mathrm{mg}$; cobalt carbonate, $5 \mathrm{mg}$; potassium iodine, $0.6 \mathrm{mg}$; selenium vanadate, $0.09 \mathrm{mg}$. Based on NRC [21] feed composition table.

\begin{tabular}{|l|c|}
\hline Ingredients & Basal diet \% \\
\hline Grain sorghum & 55.05 \\
\hline Soybean meal & 29.85 \\
\hline Gluten & 10.00 \\
\hline Carbonate calcium & 1.55 \\
\hline Lysine & 0.19 \\
\hline Molasses & 2.00 \\
\hline Vegetable oil (corn) & 0.16 \\
\hline Common salt & 0.25 \\
\hline Premix & 0.30 \\
\hline Total & 100.00 \\
\hline Calculated Chemical analysis & \\
\hline Crude protein & 25 \\
\hline Metabolizable energy (Kcal/kg) & $2945 \mathrm{Kcal} / \mathrm{Kg}$ \\
\hline Crude fiber & 2.42 \\
\hline Ether extract & 2.82 \\
\hline
\end{tabular}

Table 1: Formulation and calculated proximate analysis of the experimental basal diets.

\section{Preparation of feed additives}

Onion (Allium cepa) and garlic (Allium sativum) bulbs were peeled and carried out at laboratory of Animal Production, Faculty of Agriculture, Minia University, grated into smaller pieces and airdried. The dried garlic and onion were separately pulverized and stored in cellophane bags until required for use. The Red pepper (Capsicum annum. L) and anise (Pimpinella anisum) were purchased from local market, ground separately to a fine powder and then added in different mixture levels to basal diets resulting in five experimental groups.

\section{Measurements}

Collection of blood samples

After 5 weeks from beginning of the experiment, 3 chicks from each treatment were injected intravenously in brachial vein with $0.2 \mathrm{ml}$ of $10 \%$ suspension of sheep red blood cells to determine the activity of antibody. Three birds within each treatment were randomly selected and sacrificed, after six weeks from beginning of the treatments. Blood samples were collected in tubes contained heparin as an antic agglutination substance to study blood physical characteristics.

\section{Hematological studies \\ Total erythrocytic count $\left(\mathrm{Nx} 10^{6}\right)$}

The total red blood corpuscles (RBC's) were counted using the double improved Neubauer chamber as described by (Daice and Lewis, 1991). The total number of cells per mm3 of blood was calculated using the following equation:

Total number of RBCs $/ \mathrm{mm} 3$ blood $=\mathrm{Nx} 4000 \times 200 / 5 \times 16=\mathrm{Nx} 10^{6}$ Where " $N$ " is the mean erythrocyte count in five large squares. 


\section{Hemoglobin percentage (Hb. \%)}

Hemoglobin concentration (gm/dl) was determined using cyanomethomoglbin method. In this method, all haemoglobin derivatives except sulphaemoglobin are converted to methemoglobin using ferricyinide and cyanide ions. Methemoglobin is a stable red compound that can be measured at $540 \mathrm{~nm}$ (Campbell., 1995).

\section{Microhaematocrit, packed cell volume, (PCV \%)}

The well mixed blood was drawn into a Microhaematocrit tube $7.5 \mathrm{~cm}$ long, $1 \mathrm{~mm}$ internal diameter and one end was sealed with clay. The tube was then centrifuged in a Microhaematocrit centrifuge for 5 minutes at $15.000 \mathrm{rpm}$. The readings were made with the aid of a Microhaematocrit reader (Dacie and Lewis,1991).

\section{Wintrobe erythrocyte indices}

Calculation of the absolute values or the erythrocyte indices, namely mean corpuscular volume (MCV), mean corpuscular hemoglobin (MCH) and mean corpuscular hemoglobin concentration (MCHC) were calculated according to the following equations, according to [22].

$\operatorname{MCV}(\mathrm{F} 1)=.\frac{\text { Hct. }(\mathrm{ml} / \mathrm{dl})}{\text { RBC's (million } / \mathrm{ml})} \times 10$

$$
\operatorname{MCH}(\mathrm{Pg} .)=\frac{\mathrm{Hb} \cdot(\mathrm{g} / \mathrm{dl})}{\mathrm{RBC}^{\prime} \mathrm{s}(\text { million } / \mathrm{ml})}
$$$$
\operatorname{MCHC}(\mathrm{g} / \mathrm{dl})=\frac{\mathrm{Hb} \cdot(\mathrm{g} / \mathrm{dl})}{\operatorname{Hct} \cdot(\mathrm{ml} / \mathrm{dl})}
$$

Where F1 = (femtoliter $)=10-15$ Liter $\mathrm{Hb}=$ Hemoglobin \%, Hct $=$ Hematocrit \%, Pg = (pictogram $)=10-12$ gram and RBC's $=$ Number of Red Blood Cells eighed and expressed as a percentage of live body weight.

\section{Result and Discussion}

Effect of dietary feed additives on hematological studies

The effects of dietary feed additives supplementation (onion, garlic, red pepper and anise) at the level of $0.5 \%$ for each addi- tion on (RBC's Nx106/micro liter, PCV\%, Hb mg/dl, MCV, MCH and $\mathrm{MCHC}$ ) of Japanese quail at the end of the experiment ( 6 weeks of age) are presented in Table 2 and Figures 1 and 2. The data performed that, no significant $(\mathrm{P}>0.05)$ difference was detected in all hematological parameters studied (RBC's Nx106/micro liter, PCV\%, $\mathrm{Hb} \mathrm{mg} / \mathrm{dl}, \mathrm{MCV}, \mathrm{MCH}$ and MCHC) among dietary treatments. Whereas, there was a slightly numerically improvement $(P>0.05)$ in red blood cells count, hemoglobin and MCHC for birds fed dietary garlic. Hence, the greatest numerically improvement $(\mathrm{P}>0.05)$ in packed cell volume and MCV was recorded for birds fed dietary onion. Birds dietary anise presented the pest $(\mathrm{P}>0.05)$ values of $\mathrm{MCH}$ compared with other dietary treatments.
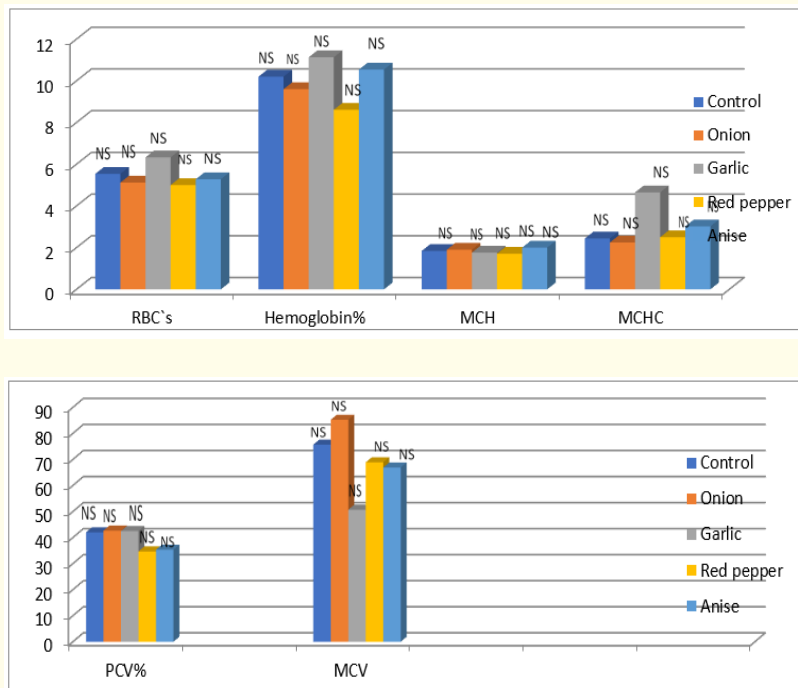

Figure 1 and 2: Effect of dietary feed additives supplementation on some hematological parameters of growing Japanese quail.

The slightly improvement in RBC's as effect of adding garlic and anise may be due to it has bioactive components like sulfur containing compounds (Alliin, Diallylsulfides and Al-licin) that act as antibacterial, antifungal, anti-parasite, antiviral, antioxidant, antithrombotic, ant cancerous and vasodilator characteristics. These results are going well with those observed by Ademola., et al. [23]

\begin{tabular}{|c|c|c|c|c|c|c|c|}
\hline \multirow{2}{*}{ Items } & \multicolumn{5}{|c|}{ Treatments ( $0.5 \%$ of each additive) } & \multirow{2}{*}{ SE } & \multirow{2}{*}{ Significance } \\
\hline & Control & Onion & Garlic & Red pepper & Anise & & \\
\hline RBC`s $\mathrm{n} \times 10^{6} /$ micro liter & 5.54 & 5.12 & 6.33 & 5.00 & 5.28 & 0.31 & NS \\
\hline Hemoglobin \% & 10.20 & 9.60 & 11.13 & 8.61 & 10.54 & 0.74 & NS \\
\hline PCV\% & 42.00 & 42.66 & 42.50 & 34.66 & 35.33 & 3.41 & NS \\
\hline $\mathrm{MCV}^{*} 10^{-5}(\mathrm{fl})$ & 75.67 & 85.22 & 50.69 & 68.89 & 66.88 & 9.16 & NS \\
\hline $\mathrm{MCH}^{*} 10^{-5}(\mathrm{pg})$ & 1.84 & 1.90 & 1.76 & 1.71 & 2.00 & 0.12 & NS \\
\hline $\mathrm{MCHC}(\mathrm{g} / \mathrm{dl})$ & 2.44 & 2.25 & 4.65 & 2.50 & 3.02 & 0.93 & NS \\
\hline
\end{tabular}

Table 2: Effect of dietary feed additives supplementation on some hematological parameters of growing Japanese quail. $\mathrm{NS}=$ Not significant; $\pm \mathrm{SE}=$ standard error. 
reported that, dietary garlic (1, 1.5 and $2 \%)$ did not effect on the $\mathrm{PCV}, \mathrm{Hb}$ and RBC concentration of the broiler chickens. Moreover, Elagib., et al. [24] found that, broiler chicks fed different levels of garlic $(0.3$ and $5 \%)$ had no significant effect $(\mathrm{P}>0.05)$ on packed cells volume and total red blood cells of birds.

\section{Effect of dietary feed additives on some immunological studies}

The effects of dietary feed additives supplementation (onion, garlic, red pepper and anise) at the level of $0.5 \%$ for each addition on Heterophil \%, lymphocyte \%, Heterophil: lymphocyte $(\mathrm{H}$ : L) ratio \%, immunoglobulin (IG ) monocyte \%, Eosinophils \%, and basophil \% of Japanese quail at the end of the experiment ( 6 weeks of age) are presented in Table 3 and Figures 3 and 4. The data re- vealed that, there was a highly significant difference $(\mathrm{P}<0.01)$ in values of total immunoglobulin between all dietary treatments. The greatest $(\mathrm{P}<0.01)$ values of total immunoglobulin were recorded for birds fed dietary garlic and anise compared with all dietary groups. No significant $(\mathrm{P}>0.05)$ difference was detected in the values of Heterophil \%, lymphocyte \%, Heterophil : lymphocyte $(\mathrm{H}$ : L) ratio \%, monocyte $\%$, Eosinophils \%, and basophil \% of Japanese quail birds fed all dietary treatments. Birds fed dietary garlic recorded the best non-significant $(\mathrm{P}>0.05)$ values of Heterophil and $\mathrm{H}: \mathrm{L}$ ratio compared with all dietary groups. While, birds fed dietary anise, control and onion recorded the greatest numerically $(\mathrm{P}>0.05)$ enhancement in the values monocyte \%, Eosinophils \%, and basophil \% respectively compared with other dietary groups.

\begin{tabular}{|c|c|c|c|c|c|c|c|}
\hline \multirow{2}{*}{ Items } & \multicolumn{5}{|c|}{ Treatments $(0.5 \%$ of each additive } & \multirow{2}{*}{ SE } & \multirow{2}{*}{ Sig } \\
\hline & Control & Onion & Garlic & Red pepper & Anise & & \\
\hline Heterophils \% & 16.55 & 18.39 & 21.06 & 18.56 & 17.02 & 3.24 & NS \\
\hline Lymphocytes \% & 53.06 & 52.94 & 43.99 & 56.30 & 48.49 & 6.53 & NS \\
\hline H/L Ratio & 31.03 & 34.56 & 48.64 & 33.81 & 38.56 & 9.26 & NS \\
\hline Total immunoglobulin & $868.79^{b}$ & $931.39^{b}$ & $1152.89^{a}$ & $978.16^{\mathrm{b}}$ & $1120.85^{a}$ & 25.55 & $* *$ \\
\hline Monocytes \% & 16.00 & 14.21 & 15.80 & 11.22 & 16.84 & 4.54 & NS \\
\hline Eosinophils \% & 8.50 & 5.88 & 8.14 & 7.14 & 8.47 & 1.82 & NS \\
\hline Basophiles \% & 5.87 & 11.76 & 11.00 & 6.76 & 9.16 & 3.12 & NS \\
\hline
\end{tabular}

Table 3: Effect of dietary feed additives supplementation on some immunological studies of growing Japanese quail. a-b Values within columns with no common superscripts are significantly different $(\mathrm{p} \leq 0.05)$. $\mathrm{NS}=$ Not significant; $\pm \mathrm{SE}=$ standard error; ${ }^{* *}=\mathrm{P} \leq 0.01$

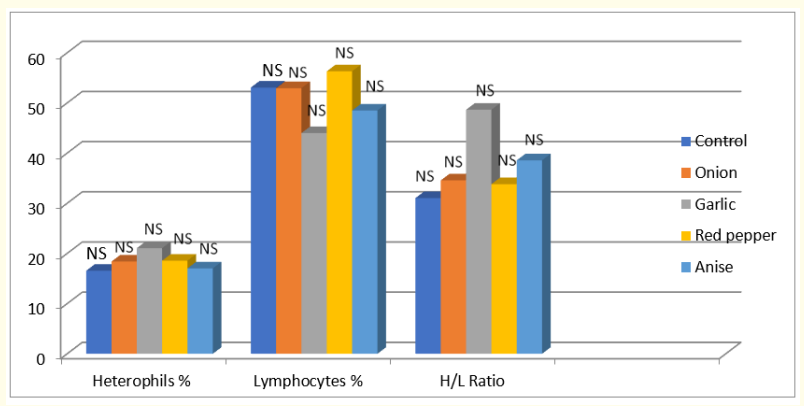

Figure 3: Effect of dietary feed additives supplementation on Heterophil s\% Lymphocytes \% and H/L Ratio of growing Japanese quail.

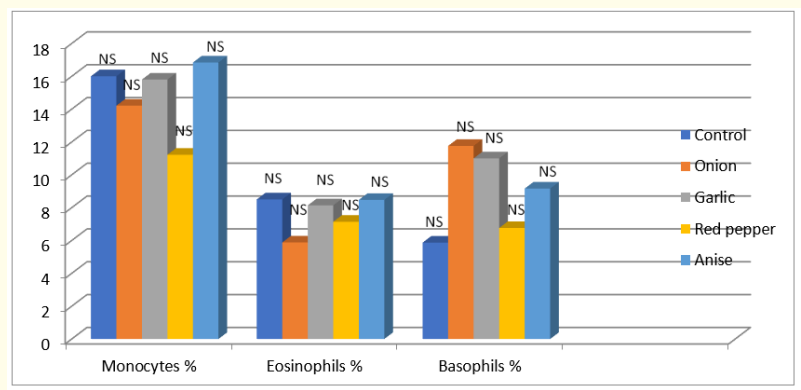

Figure 4: Effect of dietary feed additives supplementation on Monocytes \% Eosinophils \%and Basophiles \% of growing Japanese quail. 
The enhancement on immunoglobulin parameters as a result of feeding Japanese quail birds on some medical herbs may be due to that the aromatic plants is one of the ban herbal plants played an important role in maintaining human health and becoming more important due to their antimicrobial, stimulating effects on birds digestive system through increasing their digestive enzymes and improve utilization of digestive products through enhancing liver function [9]. Aromatic plants have been used traditionally in the therapy of some diseases for a long time in the world [25]. As an aromatic plant, anise (Pimpinella anisum L.) has been used in medications for a long time as a stimulating effect on digestion and as antiparasitic [26], antibacterial [27], antifungal [28] and antipyretic [29].

The present results are going well with the finding of, Yang., et al. [30] observed that, there were no significant difference $(\mathrm{P} \geq 0.05)$ on broiler chicks white blood cells including neutrophile, Eosinophils, Monocytes and lymphocytes when birds fed different levels $(0 \%, 0,3$ and $5 \%)$ of garlic supplementation. Also, Mohebbifar and Torki [31] found that, no affected of garlic supplementation (200mg/kg diet) on heterophils in of Ross broilers chicken. Furthermore, Seyed., et al. [32] found that there was no significant difference in heterophyles ratio to lymphocytes $\mathrm{H} / \mathrm{L}$ and white blood cells concentration due to supplemented broiler chicks with garlic supplementation (1\%). Kolawole., et al. [33] found that, The leukocyte or white blood cells (WBC) of broilers fed control diet and diet with $0.1 \%$ dried hot red pepper (DHRP) were similar and significantly lower than those fed diets with 0.2 and $0.3 \%$ DHRP meal.

\section{Bibliography}

1. Gill C. "More science behind "Botanical": herbs and plant extracts as growth enhances". Feed International 4 (1999): 2023.

2. Dickens J A and K D Ingram. "Efficacy of an herbal extract at various concentrations on the microbiological quality of broiler carcasses after stimulated chilling". The Journal of Applied Poultry Research 10.2 (2001): 194-198.

3. Abaza I M K. "The use of some medical plants as feed additives in broiler diets". Ph.D. Thesis, Faculty of Agriculture, Alexandria University, Egypt. (2001).

4. Al-Harthi M A. "Performance and carcass characteristics of broiler chicks as affected by different dietary types and levels of herbs and spices as non classical growth promoters". Egyptian Poultry Science Journal 22 (2002): 325-343.

5. Hassan I I., et al. "Influence of some medicinal plants on performance, physiological and meat quality traits of broiler chicks". Egyptian Poultry Science Journal 24.1 (2004): 247-266.

6. Hassan M S H., et al. "Productive, physiological and immunological effects of using some natural feed additives in Japanese quail diets". Egyptian Poultry Science Journal 27.22 (2007): 557-581.

7. European Union. "Agriculture Council”. 14th Dec 1998. Press Release No. 14127, Brussels. (1998).
8. Garcia V., et al. "Effect of formic acid and plant extracts on growth, nutrient digestibility, intestine mucosa morphology and meat yield of broilers". Journal of Applied Poultry Research 16.4 (2007): 558-563.

9. Hernandez F., et al. "Influence of two plant ex-tracts on broiler performance, digestibility, and digestive organ size". Poultry Science 83.2 (2004): 169-174.

10. Agricultural Economics. "Central administration, Agricultura Economics. Area, yield and production of Medical, Aromatic and flower plant". Economics Affairs sector, Ministry of Agric., ARE. (2005).

11. Al-Kassie GAM. "Influence of two plant extracts derived from thyme and cinnamonon broiler performance". Pakistan Veterinary Journal 29.4 (2009): 169-173.

12. Giannenas I., et al. "Effect of dietary supplementation with oregano essential oil on performance of broilers after experimental infection with eimeria tenella". Archives of Animal Nutrition Journal 57.2 (2003): 99 - 106.

13. Cross DE., et al. "The effect of herbs and their associated essential oils on performance, dietary digestibility and gut microflora in chickens from 7 to 28 days of age". British Poultry Science 48.4 (2007): 496-506.

14. Chowdhury SR., et al. "Effects of dietary garlic on cholesterol metabolism in laying hens". Poultry Science Journal 81.12 (2002): 1856-1862.

15. Faix S., et al. "Effect of cinnamomum zeylanicum essential oil on antioxidative status in broiler chickens". Acta Veterinaria Scandinavica 78 (2009): 411-417.

16. Ciftci M., et al. "The effect of anise oil (Pimpinella anisum L.) on broiler performance". International Journal of Poultry Science 4.11 (2005): 851-855

17. Kurita N., et al. "Antifungal activity and molecular orbital energies of aldehyde compounds from oils of higher plants". $A g$ ricultural and Biological Chemistry 43.11 (1979): 2365-2371.

18. Konjufca VH., et al. "Modulation of cholesterol levels in broiler meat by dietary garlic and chopper". Poultry Science Journal 76.9 (1997): 1264-1271.

19. Weber ND., et al. "In vitro virucidal effects Allium sativum (garlic) extract and components". Planta Medica 58.5 (1992): 417-423.

20. Ankri S and Mirelman D. "Antimicrobial properties of allicin from garlic". Microbes and Infection 1.2 (1999): 125-129.

21. NRC. Nutrient requirements of poultry. 9th ed. Washington, DC: National Academy Press. (1994).

22. Konuk T. "Practice of Physiology-1 "Pratik Fizyoloji-1". Ankara: Ankara University Veteriner Fakultesi, A.U. Basimevi, 314 (1975).

23. Ademola SG., et al. "Growth and Hematological parameters of Broilers Fed Garlic ,Ginger and their mixtures". Agricultural Science Research Journal 5.1 (2009): 99-104. 
24. Elagib HAA., et al. "Effect of Dietary Garlic (Allium sativum) Supplementation as Feed Additive on Broiler Performance and Blood Profile". Journal of Animal Science Advances 3.2 (2013): 58-64

25. Osman NE., et al. "The Effect of an Essential Oil Mix Derived from Oregano, Clove and Anise on Broiler performance". International Journal of Poultry Science 4.11 (2005):879-884.

26. Cabuk M., et al. "Anitimicrobial property of the essential oils isolated from aromatic plants and using possibility as alternative feed additives: II National Animal Nutrition Congress 18-20 Septemper, (2003): 184-187.

27. Tabanca N., et al. "Antimicrobial compounds from Pimpinella species growing inTurkey". Planta Medical 69.10 (2003): 933938.

28. Soliman KM and Badea RI. "Effect of oil extracted from some medicinal plants on different mycotoxigenic fungi". Food and Chemical Toxicology 40.11 (2002): 1669-1675.

29. Afifi NA., et al. "Some pharmacological activities of essential oils of certain umbeliferous fruits". Veterinary Medical Journal Giza 42.3 (1994): 85-92.

30. Yang WZ., et al. "Effects of garlic and juniper berry essential oils on runinal fermentation and on site and extent of digestion in lactating cows". Journal of Dairy Science 90.12 (2007): 5671-5681.

31. Mohebbifar A and Torki M. "Growth performance and humoral response of broiler chicks fed diet containing graded levels of ground date pits and garlic and thyme". Global Veterinaria 6.4 (2011): 389-398.

32. Seyed MM and Taklim S MM. "Investigating the effect of fenugreek seed powder and garlic powder in the diet on immune response of commercial ayinghens' egg". Indian Journal of Scientific Research 3.1 (2014): 277-283.

33. Kolawole Daniel A., et al. "Hot Red Pepper (Capsicum annum L.) Meal Enhanced the Immunity, Performance and Economy of Broilers Fed in Phases". Journal of Biology, Agriculture and Healthcare 7.8 (2017).

\section{Volume 3 Issue 9 September 2019}

(C) All rights are reserved by SA Abd El- Latif., et al. 